\title{
Hydro-economic Modeling in River Basin Management: Implications and Applications for the European Water Framework Directive
}

\author{
I. Heinz • M. Pulido-Velazquez • J. R. Lund • J. Andreu
}

Received: 1 December 2005 / Accepted: 3 July 2006 / Published online: 4 January 2007

(C) Springer Science + Business Media B.V. 2007

\begin{abstract}
Economic ideas and processes are becoming increasingly integrated with more traditional engineering and hydrologic models of water management problems. Combining economic management concepts and performance indicators with an engineering-level of understanding of a hydrologic system can provide results and insights more directly relevant for water management decisions and policies. When such models are developed and used with involvement of stakeholders, they can become a basis for shared understanding of water problems as a foundation for negotiated management and policy solutions. When implemented with optimization software, integrated hydro-economic models also can suggest promising innovative solutions for policy-makers to consider. Their applications to river basin management problems are reviewed. Economic and integrated economic-engineering-hydrologic modeling is then discussed in the context of the evolving European Water Framework Directive. Relevant items are cost recovery and water pricing, cost-effectiveness of water management measures, and public participation in decision processes.
\end{abstract}

Key words water management $\cdot$ modeling $\cdot$ economics $\cdot$ environmental costs $\cdot$ cost recovery $\cdot$ water pricing $\cdot$ water allocation $\cdot$ cost-effectiveness $\cdot$ cost benefit analysis $\cdot$ optimization $\cdot$ water policy $\cdot$ European Union

I. Heinz $(\bowtie)$

Institute of Environmental Research,

University of Dortmund, Dortmund, Germany

e-mail: i.heinz@infu.uni-dortmund.de

M. Pulido-Velazquez $\cdot$ J. Andreu

IIAMA (Institute for Water and Environmental Engineering),

Technical University of Valencia, Valencia, Spain

J. R. Lund

Department of Civil and Environmental Engineering,

University of California, Davis, USA 


\section{Introduction}

Water management is becoming increasingly controversial in much of the world as water demands grow, diversify, and include more complex and extensive environmental concerns. The many uses and interests regarding water management have led to more decentralized governance and management, involving a wide variety of interests, stakeholders, and management options. This has posed challenges to traditional analytical methods, approaches for managing and governing water, and our understanding of the roles and functions of water systems in society. The need for better involvement of diverse stakeholders in modeling and integrated water management is increasingly apparent. The European Water Framework Directive (WFD) requires active involvement of different stakeholders, such as farmers, industries, municipalities, households, authorities and NGOs, in integrated water management.

Economics brings several contributions to this situation. Economics traditionally offers a basis for societal evaluation of alternatives in water management. However, economic theory and methods also help us understand systems with decentralized performance and management. For such decentralized decision-making, economic theory provides useful and insightful policy ideas, such as various market, pricing, financial, taxation and regulation solutions. These concepts and methods are especially useful for integrating diverse options over different parties in complex water management systems. Providing a common basis for understanding operation and performance is essential for participatory planning. Integrating economic ideas, objectives and methods into the analysis of river basin management can yield new approaches, and insights to governance, management, and technical performance.

The joint application of economic and engineering ideas, objectives and methods have long been useful for analyzing problems and identifying promising solutions where multiple users compete for resources. Economic, engineering and political aspects have always been important for effective water management (Frontinus 97a.d.). Many of the most fundamental concepts of economics originally were developed from the engineering of large public water resource projects (Elelund and Hebert 1999). One of the earliest descriptions of an economic demand curve was for urban water delivery, in 1853 by the French engineer Jules Dupuit:

... the enemy comes, blockades the city, diverts the stream; the inhabitants have now at their disposal only the drops that escape from the works of the enemy or that of a few wells that dry up easily; there is no longer any more available for all usages, everyone is more or less deprived; water then has a value. ... If the enemy, perfecting its works, succeeds in progressively diminishing the quantity of water that enters the city, its price is going to rise more and more, and one will not care to exchange a liter of it for a diamond (Dupuit 1853, translated by Elelund and Hebert 1999).

Today, integrated water management seeks to conjunctively address a widening variety of water management objectives and interests, including water supply, water quality, flood control, conservation of aquatic ecosystems, recreation, shipping and fisheries. Integration also can improve management of water-related conflicts (Bish 1982). By integrated basin wide analysis of water demands and supply opportunities, overall improvements can be better identified and negotiated.

Water policies need not be limited to mandatory rules (standards) but may also include economic instruments such as prices, taxes (e.g., for pollution or pumping), economic incentives (e.g., agri-environmental incentive programs), and market-based and self- 
regulatory policy approaches (e.g., tradable water rights and permits, voluntary agreements between stakeholders). Having a wider range of solution options should aid parties in negotiating better overall solutions. However, policy makers are often unaware or uncertain about the impacts of alternatives. Simulation and optimization models can aid development and implementation of integrated water management alternatives that respond to socioeconomic and legal-political objectives. Such modeling is possible due to enormous advances in computing and information technologies. Information technology standards are especially significant to help link individual computer models and data sets created for different individual problems. Linking procedures avoid the construction of a single complex water management model, require fewer changes of the domain-specific models, and reduce re-programming (Westen et al. 2004). Such approaches may also facilitate the integration of stakeholder concerns.

The next section reviews which role economic concepts and methods can have in river basin management. This is followed by a discussion of current applications of economic approaches and models to river basin management. Some implications for the European Union's Water Framework Directive (WFD) (EU Commission 2000) are then discussed including considerations on the role of hydro-economic models in involving the various interests of stakeholders in water management pursuant to participatory requirements laid down in the WFD. Finally, a model example will be presented.

\section{Roles for Economic Approaches in River Basin Management}

Economic concepts and methods can contribute to overall river basin management especially with regard to future water demands, financial assessment, economic evaluation, economically efficient measurements and policy strategies (pricing, taxes, incentives, markets, assurance and voluntary agreements) and conflict resolution in negotiation processes. These ideas, when integrated with hydrologic and engineering analysis, offer decision-oriented approaches to analysis that broaden the range of management and policy alternatives.

\subsection{Water Demand and Value Estimation}

Estimating demand quantities for water services and their economic values is central to understanding many water management problems. Demands for water services are traditionally estimated as "requirements" for particular purposes. Such "requirements" are measured as the single-valued delivery quantities "needed" to support a level of production or population under a particular set of water use technologies and water use behaviors, with no ability to reduce water use. However, water "requirements" are simplistic representations of how water users decide how much water to use and how much they value water use. Moreover, this representation leads to deadlock or excessive expense when the sum of all desired water uses exceeds available water supplies. Ironically, the first rigorous realization of this problem and modern economic conceptualization of demand were developed by the French water engineer Dupuit in 1844 (Dupuit 1844; Elelund and Hebert 1999).

Water deliveries benefit individuals and contribute to productive activities in agriculture, commerce, and industry. The quantitative valuation of these benefits to different users and purposes is important within participatory approaches to management. The participatory development of economic values for water use provides a common economic indicator of 
value. The conventional willingness to pay interpretation of such water demands provides a basis for cost allocation from a beneficiaries pay perspective. There is a considerable literature on valuation of water for its many uses, including market and market-surrogate methods, hedonic pricing, and contingent valuation (Young 2005). Many of these methods take a willingness to pay approach to valuing water deliveries and use.

\subsection{Financial and Cost Allocation Studies}

Financial studies are required to support investments in water services and their sustainability. Financial studies estimate the net monetary income of projects or alternatives to particular institutions, groups, or users, indicating the net financial benefit or cost to each entity. Any involved agency will want estimates of changes in revenues, expenditures, and budgets that would accompany particular water management alternatives under different conditions. Financial studies support the organizational and interest-based prudence of particular water management alternatives. Modern financial evaluations provide a prudent foundation for organizations and interest to innovate and deviate from traditional policies. Finance is a special concern in developing countries (Winpenny 2003).

When financial responsibility for a project accrues to several beneficiaries, its total cost must be allocated among these groups. In some cases cost allocation problems related to financial strategies can be simulated as negotiation processes and formulated as cooperative games and analyzed using game-theory (Young et al. 1982).

\subsection{Valuation of Economic Benefits of Water Policies and Water Projects}

Economic evaluation studies (economic benefit-cost studies) have a broader perspective than financial studies, considering financial effects as well as economic valuations of nonrevenue benefits and non-expenditure costs, usually to a broader set of parties. Water supply reliability and quality often have economic values beyond the revenues and expenditures of the water supply utility. Whereas a financial study typically considers net revenues to a water agency or a specific water user, economic evaluations commonly examine the broad range of economic effects to a region (nation, state, region, or locality) or groups (fishermen, farmers, power users). The ideal economic evaluation considers, in the words of the 1936 US Flood Control Act, all benefits and costs "to whomsoever they accrue" (Griffin 2005). Economic evaluation can be used in a larger policy context to consider the trade-offs of economic performance against other forms of performance, such as economicecological tradeoffs (US Water Resources Council 1983; Disco 2002; Burke et al. 2004; Cai and Rosegrant 2004). By applying such a broad approach, economic evaluation can provide useful information to stakeholders and a basis for larger governmental support of stakeholder-negotiated agreements.

\subsection{Economic Instruments and Policy Strategies}

Economic theory provides a variety of policy strategies and instruments for managing river basin problems (Table 1). Different institutional approaches (centralized and decentralized governance, privatization, regionalization, water markets, etc.) can be studied from the point of view of social acceptance and economic efficiency. Economic instruments such as pricing, taxation, subsidies, insurance, provide incentives to behave in ways that contribute towards both self-interest and to the broader society welfare. These economic management 
Table 1 Economic assessment criteria and policy options for water management

\begin{tabular}{lll}
\hline Economic criteria & Water policies and institutions & \\
\hline Cost-effectiveness & Regulations/Planning & Markets (water rights) \\
Benefit-cost indicators & Pricing & Privatization \\
Economic affordability & Taxes & Regionalization \\
& Subsidies & Centralization \\
& Insurance & De-centralization \\
\hline
\end{tabular}

approaches enrich the range of solutions available to water managers and policy makers. Examples include pricing to encourage water use efficiency and discourage wasteful uses of water, markets to flexibly reallocate water use in ways which compensate water-right holders based on the current water right systems, and the use of flood insurance to discourage settlement in floodplains.

Applications of economic water management concepts include water pricing policies for irrigation (e.g., Mejías et al. 2004; Bazzani et al. 2004) and urban supply (e.g., Garcia and Reynaud 2004) water rights and marketing (e.g., Booker and Young 1994); agricultural policies (e.g., Mejías et al. 2004), salinity (e.g., Lee and Howitt 1996) and pollution control (e.g., Shortle and Dunn 1986). Many of these investigations recognize the importance of stakeholder involvement.

\subsection{Negotiation Concepts}

Economic ideas also pertain to the negotiations inherent in regional water management. These negotiations include explicit bargaining between construction companies and water agencies, the decisions of water users to accept meter readings or bill payments (in some countries), conditions of water transfer between local and regional water agencies, and countless other explicit and tacit agreements which must be reached for a water system to function well. In all such cases, game theory concepts can provide insights into how to successfully conclude such unavoidable negotiations (Raiffa 1984).

\section{Economics and Participatory Aspects in Water Management Models}

The principal advantages of computer models of water systems are (1) they force us to be specific in representing our understanding of a system and identify gaps in our knowledge, (2) they allow us to assess if simplified representations of uncertain aspects are likely to be adequate, and (3) they allow us to apply our current knowledge to evaluate management alternatives.

Just as river basins are complex systems, so are detailed management and scientific models of complex systems. Hydro-economic approaches to modeling river basins are typically simulations, with increasing use of optimization. Hydrologists, engineers, economists and other social scientists are to be involved in developing these models, with increasing involvement from stakeholders to ensure that models address their concerns and can be understood and trusted by diverse interests in a basin (Lund and Palmer 1997; Palmer et al. 1999; Andreu et al. 2006).

Integrated water management plans for entire river basins or watersheds are increasingly required. The European Framework Directive (WFD) (EU Commission 2000) prescribes 
Table 2 Some spatial, temporal, and process options

\begin{tabular}{lll}
\hline Spatial scale & Temporal scale & Processes \\
\hline Individual water user & Daily or hourly (water quality, floods, hydraulics) & Water flow \\
Local water districts & Monthly (water supply) & Pollution \\
Regional & Annual & Energy use and production \\
National & Steady state vs. dynamic & Economic \\
International & & Ecosystems \\
\hline
\end{tabular}

establishing such plans in each EU Member State with the application of economic principles. Some common aspects, different types of hydro-economic models and the institutional and participatory roles of modeling are reviewed below.

\subsection{Elements of Integrated River Basin Models}

Construction of any hydro-economic management model requires decisions on representing several common aspects. These decisions should depend on the present and anticipated uses and audiences of the model and model results. Some of these choices are discussed below.

\subsubsection{Representations of Space, Time, and Processes}

The model must have equations and data that represent processes within the water system at spatial and temporal resolutions appropriate for the management problem. Some of these modeling decisions are summarized in Table 2. At the usual monthly time scale in which river basin management models work, surface water flow can be represented by simple mass-balance in a flow network. However, the simulation of groundwater flow and surfacegroundwater interactions within a conjunctive use model usually requires more complex modeling approaches (Gorelick 1983; Pulido-Velazquez et al. 2006). Economic, water quality, and ecological processes also must be represented.

\subsubsection{Management Decisions}

Models used for management and policy analysis must include management decisions. River basin management can involve a wide range of options and alternatives. Ideally, management decisions would be represented as decision or design variables related to different scenarios. Box 1 summarizes water management decisions for water supply purposes.

\section{Box 1. Examples of Water Management Options}

\footnotetext{
Demand Management

Water use efficiency technologies and behaviors (water conservation for each use)

Pricing

Subsidies and taxes

Regulations (water rights, water quality, contract authority, quantity-rationing, etc.)

Water transfers and exchanges (within and/or between regions/sectors)

Insurance (drought or flood insurance)
} 


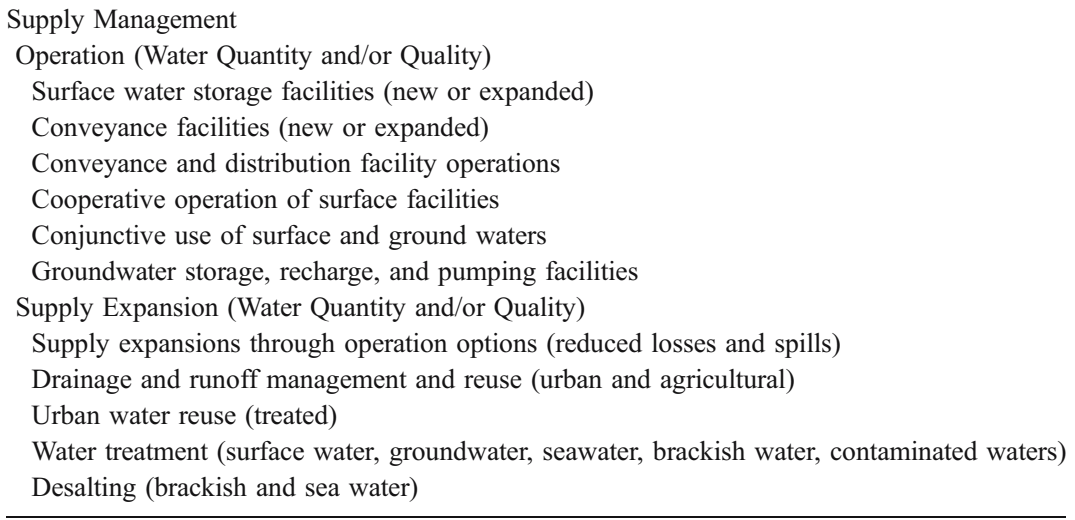

\subsubsection{Performance Indicators}

The performance of management alternatives can be assessed from many perspectives and measured in various ways. Performance characterization in hydro-economic models should reflect the perspectives of relevant decision-makers and stakeholders. Box 2 shows some common indicators to assess economic performance.

\section{Box 2. Economic Performance Criteria}

Net financial benefit for particular groups or institutions Cost-effectiveness of achieving water-related objectives

Net economic benefits (local, regional, or national)

Consumers' and producers' surplus (excess of willingness to pay above costs to users)

Multi-objective assessments, including both economic and non-economic indicators or performance

\subsection{Different Types of Hydro-economic Models}

\subsubsection{Holistic vs. Compartmental Modeling}

Integrated hydrologic-economic models can be classified as holistic or compartmental (Cai et al. 2003). Integrated compartmental models are organized into independent modules, and only input/output data are transferred between them (Lekoff and Gorelick 1990). Under this approach, combined simulation and optimization models can be used. Feedback loops or iterations may be needed, requiring appropriate model interfaces among model components (Westen et al. 2004; Dirksen 2004). The EU Commission funded research project "HarmonIT" has devoted considerable energy to developing the common software framework "Open Modeling Interface and Environment" for linking component simulation models (http://www.harmonit.org; htp://www.openmi.org).

Holistic models have a single control unit, with all modeled aspects embedded in a consistent model (Booker and Young 1994; Cai et al. 2003). The representation of complex large-scale systems using optimization techniques provides great flexibility and effective- 
ness to simulate generalized large-scale systems. However, most holistic hydrologiceconomic optimization models at the basin scale must significantly simplify some system aspects (such as groundwater-surface interrelationships or hydrologic foresight) (Draper et al. 2003).

\subsubsection{Simulation vs. Optimization Models}

Hydro-economic simulation models are used to examine and evaluate specific "what if" scenarios, consisting of particular management decisions under particular scenario conditions (such as water demands or climate). Simulation models are relatively precise surgical tools for examining very specific conditions. They are excellent for exploring precise and specific management policies, and for exploring the ability of our quantitative understanding to mimic field behavior. If carefully constructed and linked within a common framework, simulation models of components of a larger water resource system can be developed, tested, and employed independently, and then assembled or linked to examine more integrated decisions and behaviors (Jenkins and Lund 2000).

While simulation models can estimate the effects of specific alternative water management strategies, hydro-economic optimization tools can identify promising combinations of diverse actions within natural and human-made constraints, such as availability of water resources and statutory rules. Optimization models help identify "what's best" in a broad sense, for refinement and testing with detailed simulation studies and negotiations.

As the number of options increases, simulation modeling alone cannot examine anything remotely close to all possible alternatives. The number of runs required to examine by simulation all alternatives consisting of combinations of $n$ binary management options is $2^{n}$. Even with the most efficient simulation software, decreasing the time and cost of a single simulation run will not overcome this combinatorial conundrum. Searching over large complex solution spaces for promising combinations of solutions requires optimization modeling. Optimization models typically employ a simpler formulation of the system than simulation models. But the algorithms of an optimization model allow for identification of promising alternatives given a wide range of management options. Nevertheless, optimization models have their own limitations, requiring simplifications to accommodate optimization solution algorithms. Combined simulation-optimization methods allow optimization models to identify promising combinations of options, with simulation modeling to test and refine optimization model results (Lund and Ferreira 1996).

\subsection{Current Status and Applications of Hydro-economic Modeling}

Hydro-economic models have been widely developed by academic researchers, but have moved into practice in only a few areas. Hydro-economic models are widely applied for hydropower operations, particularly for private power companies. Here, economic objectives are very clear and the economic benefits of explicitly integrating economic, engineering, and hydrologic aspects of the problem are appreciated directly by water management institutions. Where economic performance is less directly important to management institutions, water system models with explicit economic representations have found less use. A summary of some recent applications appears in Table 3.

An overview of current hydro-economic models mostly in the European Member States was presented at an expert meeting on economics in water management models in Copenhagen in November 2004. (http:/www.hit.infu.uni-dortmund.de/login.html; userid: 
Table 3 Some recent examples of hydro-economic models

\begin{tabular}{|c|c|c|c|}
\hline Basin & Purposes & Economic indicator & References \\
\hline Missouri R., USA & $\begin{array}{c}\text { Power, flood, water } \\
\text { supply, navigation }\end{array}$ & $\begin{array}{l}\text { National economic } \\
\text { performance }\end{array}$ & Lund and Ferreira 1996 \\
\hline Columbia R., USA & $\begin{array}{l}\text { Hydropower, flood, } \\
\text { fisheries, navigation }\end{array}$ & $\begin{array}{l}\text { National economic } \\
\text { performance }\end{array}$ & HEC 1996 \\
\hline California, USA & $\begin{array}{l}\text { Water supply, } \\
\text { hydropower }\end{array}$ & $\begin{array}{l}\text { Statewide economic } \\
\text { performance }\end{array}$ & $\begin{array}{l}\text { Draper et al. 2003; } \\
\text { Jenkins et al. } 2004\end{array}$ \\
\hline $\begin{array}{l}\text { Southern } \\
\text { California, USA }\end{array}$ & $\begin{array}{l}\text { Water supply, water } \\
\text { marketing }\end{array}$ & $\begin{array}{l}\text { Financial, regional } \\
\text { performance }\end{array}$ & $\begin{array}{l}\text { http://www.sdcwa.org } \\
\text { http://www.mwdh2o.com } \\
\text { Pulido-Velazquez et al. } 2004\end{array}$ \\
\hline California, USA & Hydropower & Power revenues & Jacobs et al. 1995 \\
\hline $\begin{array}{l}\text { San Antonio, USA } \\
\text { (Edwards Aquifer) }\end{array}$ & $\begin{array}{l}\text { Water supply, } \\
\text { environmental }\end{array}$ & $\begin{array}{l}\text { Economic and } \\
\text { environmental }\end{array}$ & $\begin{array}{l}\text { Watkins and McKinney } 1999 \text {; } \\
\text { McCarl et al. } 1999\end{array}$ \\
\hline $\begin{array}{l}\text { Colorado River, } \\
\text { USA }\end{array}$ & $\begin{array}{l}\text { Water marketing for } \\
\text { water supply }\end{array}$ & $\begin{array}{l}\text { Regional economic } \\
\text { performance }\end{array}$ & Booker and Young 1994 \\
\hline $\begin{array}{l}\text { Syr Darya River, } \\
\text { Central Asia }\end{array}$ & $\begin{array}{l}\text { Water and } \\
\text { agronomic } \\
\text { management }\end{array}$ & $\begin{array}{l}\text { Irrigation benefit with } \\
\text { environmental tax }\end{array}$ & Cai et al. 2003 \\
\hline Oregon, USA & $\begin{array}{l}\text { Environmental and } \\
\text { irrigation }\end{array}$ & $\begin{array}{l}\text { Farmers' net benefit, } \\
\text { including water bank }\end{array}$ & Burke et al. 2004 \\
\hline $\begin{array}{l}\text { Adra River Basin, } \\
\text { Spain }\end{array}$ & Water marketing & $\begin{array}{l}\text { Aggregated and } \\
\text { individual benefits }\end{array}$ & Pulido-Velazquez et al. 2006 \\
\hline $\begin{array}{l}\text { Greek islands, such } \\
\text { as Paros, Greece }\end{array}$ & Water allocation & $\begin{array}{l}\text { Economic value of } \\
\text { water }\end{array}$ & Assimacopoulos et al. 2005 \\
\hline Po Basin, Italy & $\begin{array}{l}\text { Water use in } \\
\text { agriculture }\end{array}$ & Water pricing policies & Bazzani et al. 2004 \\
\hline $\begin{array}{l}\text { Elbe Basin, } \\
\text { Germany }\end{array}$ & $\begin{array}{l}\text { Integrated water } \\
\text { management }\end{array}$ & $\begin{array}{l}\text { Economic } \\
\text { development }\end{array}$ & http://www.glowa-elbe.de \\
\hline Czech Republic & Wastewater disposal & Least cost treatment & Krejcik 2004 \\
\hline $\begin{array}{l}\text { Rönnea Catchment, } \\
\text { Sweden }\end{array}$ & $\begin{array}{l}\text { Eutrophication } \\
\text { control }\end{array}$ & $\begin{array}{l}\text { Cost-effective } \\
\text { mitigation programs }\end{array}$ & Jöborn et al. 2005 \\
\hline The Netherlands & $\begin{array}{l}\text { Environment and } \\
\text { agriculture }\end{array}$ & $\begin{array}{l}\text { Maximisation of } \\
\text { economic net benefits }\end{array}$ & Dirksen et al. 2005 \\
\hline
\end{tabular}

Copenhagen, password: EconoMod). A similar conference took place in Valencia on 30-31 January 2006 (http://www.upv.es/aquatool/jornadas). With the exception of hydropower systems, few hydro-economic models are currently applied in real-life water management due to the complex interrelationships between the hydrological, socio-economic and political processes in river basins.

Nevertheless, the presentations showed a wide spectrum of potential contributions of hydro-economic modeling to an integrated water management, including:

- Integration of water supply and demand management

- Development of better integrated solutions to water scarcity

- Optimizing reservoir operations with competing water demands

- Modeling storm water management and economic flood control options

- Development of cost-effective solutions for water quality objectives

- Incorporation of climate change impacts

- Software interfaces for interacting hydrologic-engineering and economic models 
- Simulation and optimization of hydro-economic processes in watersheds and river basins

- Economic assessment of various water policies, such as standards, pricing, markets and entitlement reallocation

- Integration of various water domains with socio-economic and political considerations

- Support involvement of stakeholders with different objectives in model development, application, and water management decisions.

A gap currently exists between many existing sophisticated hydrologic models and modeling of regional economic systems and processes in watersheds for management purposes. To develop harmonized modeling tools and methods for integrated water management at river basin or sub-basin scales, CatchMod (for Catchment Water Modelling) represents a cluster of nine research projects funded by the EU Commission in the Fifth Framework Programme (Table 4). Harmoni-CA has been additionally established to ensure communications between these and further EU-funded water-related research projects (http://www.harmoni-ca.info). Although CatchMod projects emphasize hydrology or engineering issues, economics is embedded in many of these projects.

What are the potential contributions of hydro-economic modeling to meet the requirements of the European Framework (WFD)? The next section examines the major challenges derived from this important regulation for the 25 current European Member

Table 4 Economic issues in the CatchMod cluster

\begin{tabular}{|c|c|c|}
\hline Cluster element & Objective & Main economic subject \\
\hline BMW & $\begin{array}{l}\text { Benchmarking models: criteria to assess } \\
\text { integrated models for the use in } \\
\text { implementing the WFD }\end{array}$ & $\begin{array}{l}\text { WFD requirements regarding the } \\
\text { cost-effective measures in water } \\
\text { management }\end{array}$ \\
\hline CLIME & $\begin{array}{l}\text { Methods/models to manage lakes and } \\
\text { catchments regarding climate changes }\end{array}$ & $\begin{array}{l}\text { The economic and social impacts } \\
\text { of changes in the water quality of lakes }\end{array}$ \\
\hline EUROHARP & $\begin{array}{l}\text { Harmonised methods/tools to quantify } \\
\text { nutrient losses from diffuse sources } \\
\text { (in WFD context) }\end{array}$ & $\begin{array}{l}\text { Quantify response in nutrient losses to land } \\
\text { use and agricultural management practices } \\
\text { regarding social and economic activity }\end{array}$ \\
\hline HarmoniQuA & $\begin{array}{l}\text { Method and guidelines to improve the } \\
\text { quality of river basin modeling }\end{array}$ & $\begin{array}{l}\text { Incorporation of water economics in a } \\
\text { standard for good modeling practice }\end{array}$ \\
\hline HarmoniRIB & $\begin{array}{l}\text { Tools/techniques to tackle uncertainty } \\
\text { in water management (in WFD context) }\end{array}$ & $\begin{array}{l}\text { Uncertainties in the economic } \\
\text { analysis of water management }\end{array}$ \\
\hline HarmonIT & $\begin{array}{l}\text { IT system/tools to simplify linking models } \\
\text { by creating an Open Modelling Interface } \\
\text { and Environment (OpenMI) for integrated } \\
\text { water modeling }\end{array}$ & $\begin{array}{l}\text { Coupling hydrological with economic } \\
\text { models/tools by using a generic IT } \\
\text { framework. Migration of economic models } \\
\text { by making them "OpenMI-compliant" }\end{array}$ \\
\hline TempQsim & $\begin{array}{l}\text { Incorporate ephemeral waters into existing } \\
\text { instream water quality models for } \\
\text { Mediterranean and semiarid catchments }\end{array}$ & Not applicable \\
\hline $\begin{array}{l}\text { TISZA River } \\
\text { Project }\end{array}$ & $\begin{array}{l}\text { Integrated models for supporting } \\
\text { water- and environmental management } \\
\text { decisions (Tisza river basin in Hungaria, } \\
\text { Romania, Slowakia, Ukraine, Yugoslavia) }\end{array}$ & $\begin{array}{l}\text { Efficient water management decisions } \\
\text { for water allocation, wetlands, floods, } \\
\text { agricultural water use and fisheries, } \\
\text { diffuse and point pollution sources, } \\
\text { and eutrophication processes }\end{array}$ \\
\hline TRANSCAT & $\begin{array}{l}\text { Decision support for water management } \\
\text { in border regions (in WFD context) }\end{array}$ & $\begin{array}{l}\text { Cost-effective strategies for an integrated } \\
\text { water management for transboundary } \\
\text { catchments }\end{array}$ \\
\hline
\end{tabular}


States. One hydro-economic model - the Aquatool DSS (Andreu et al. 2006) - will be used to illustrate how such models can help address some of these challenges.

\section{Implementing the WFD: How can Hydro-economic Models Help?}

The October 2000 WFD provides a framework for the protection of water resources in the EU. Initially, EU legislation on water focused on specific environmental problems of public health and water quality risks. During the late 1990s, responding to calls to improve the ecological status of surface and ground waters, the EU Commission adopted the WFD, which seeks to provide an integrated approach to sustainably manage water resources (Morris 2004). A "good" water status must be attained for all natural waters by 2015 or in the case of heavily modified or artificial water, good ecological potential and good chemical status must occur within an agreed and properly justified extended time scale. Member States must characterize each river basin, specify a program of measures to achieve environmental objectives, and establish river basin management plans.

\subsection{Economic Elements in the WFD}

The Directive clearly integrates economics into water management and policy making. To meet the environmental objectives, the Directive calls for applying economic principles (e.g., the polluter pays principle), approaches (e.g., cost-effectiveness analysis), and instruments (e.g., water pricing). Economics is to have a decisive role in the development of river basin management plans and the design of water pricing policies. The WFD has assigned new roles to economics in water policy from financial studies to economic valuation (considering the economic value of water), at local to river basin scales, and to support project selection, strategies, and programs (Strosser 2004).

The key requirements concerning economics supporting the implementation of the WFD are (WATECO 2002):

- Economic analysis of water use (such as forecast of water supply and demand, costs and prices of water services and investments needed and current level of cost recovery) (Article 5 and Annex III).

- Water price policies providing incentives for efficient and sustainable water use (Article 9).

- Ensuring an adequate contribution of the various water uses (such as industry, households and agriculture) to the recovery of water service costs based on the economic analysis and taking into account the polluter pays principle (Article 9).

- Implementation of the most cost effective combination of measures to achieve the good water status at each river basin by 2012 (Article 11).

- Justification of potential time and objective derogation when disproportionate costs are identified (Article 4).

\subsubsection{Economic Analysis of Water Use and Level of Cost Recovery}

Member States describe in their 2004 Art. 5 reports the current economic situation of water uses in the various basins. This analysis assesses current water uses and their economic importance, and contain estimates of volumes, prices and costs associated with water 
services, and forecasts of future trends related to their key economic drivers. The detail of the analysis should be enough to reflect how important water is for the socio-economic development of the river basin, to identify the significant water uses, and to estimate the current level of cost recovery for water services. It should also pave the way for costeffective analysis of measures to achieve the environmental objectives and the analysis of potential disproportionate costs (Annex III, WFD; WATECO).

\subsubsection{Selection of the Most Cost Effective Combination of Measures to Achieve the Good Water Status at Each River Basin and Justification of Disproportionate Costs}

The most cost-effective program of actions should be selected to meet the WFD environmental objectives (CEA analysis). These programs must be established by 2009 and be operational in 2012 (Art. 11, WFD). Some pioneering pilot studies have been reported. Some of these studies present a single indicator of cost-effectiveness, estimated as total cost divided by total effect (or contribution to realizing objectives), to propose allocation of technical actions among regions and sectors for attaining the WFD objectives with the least cost (e.g., MMA 2002; Van der Veeren 2005). Other approaches have employed cost-effectiveness analysis as a trade-off process, using tables combining qualitative and quantitative information to support the decisions (Interwies et al. 2004).

Even a least cost program of actions to achieve EU targets may technically infeasible or result in disproportionately high costs compared to the benefits obtained ("disproportionate costs"). In this case, the WFD offers the possibility of temporal derogation or less stringent objectives (Art. 4.4, 4.5, and 4.7). This step might require assessment and comparison of social and economic costs and benefits of the program of actions through benefit-cost analysis. Based on this information, it is possible to substantiate adjustment to the WFD objectives. These adjusted objectives will then form the starting point of a new CEA analysis, so that the search for the optimum set of actions can become an iterative process (van der Veeren 2005). Approaches at single user/economic sector scales as affordability or Best Available Technology (BAT) also are relevant. Here, the distributional implications are to be considered. Thus, the decision to be made by politicians on the implementation of good surface water status in river basins and the follow-up costs must embedded in transparent participatory processes (Pahl-Wostl 2002; HarmoniCOP 2005; HarmoniQuA 2006).

\subsubsection{Definition of Water Pricing Policies}

Water pricing is a basic instrument for managing water demands and can promote equity, efficiency, and sustainability (Rogers et al. 2002). However, many practical difficulties exist for defining, measuring, and implementing pricing for full cost recovery (Dinar and Mody 2004), and water price is often far from representing the "true" economic value of water or being a proper incentive for more efficient water use.

According to the WFD, Member States must implement a pricing policy for 2010 that provides adequate incentives for efficient water use (contributing to the environmental objectives), and ensure "adequate contribution of the different water uses... to the recovery of the cost of water services" (Art. 9). However, a member state may consider the "social, environmental, and economic effects of the recovery" and they will not be in breach of the Directive if it decides "in accordance with established practices" not to apply the provisions. 


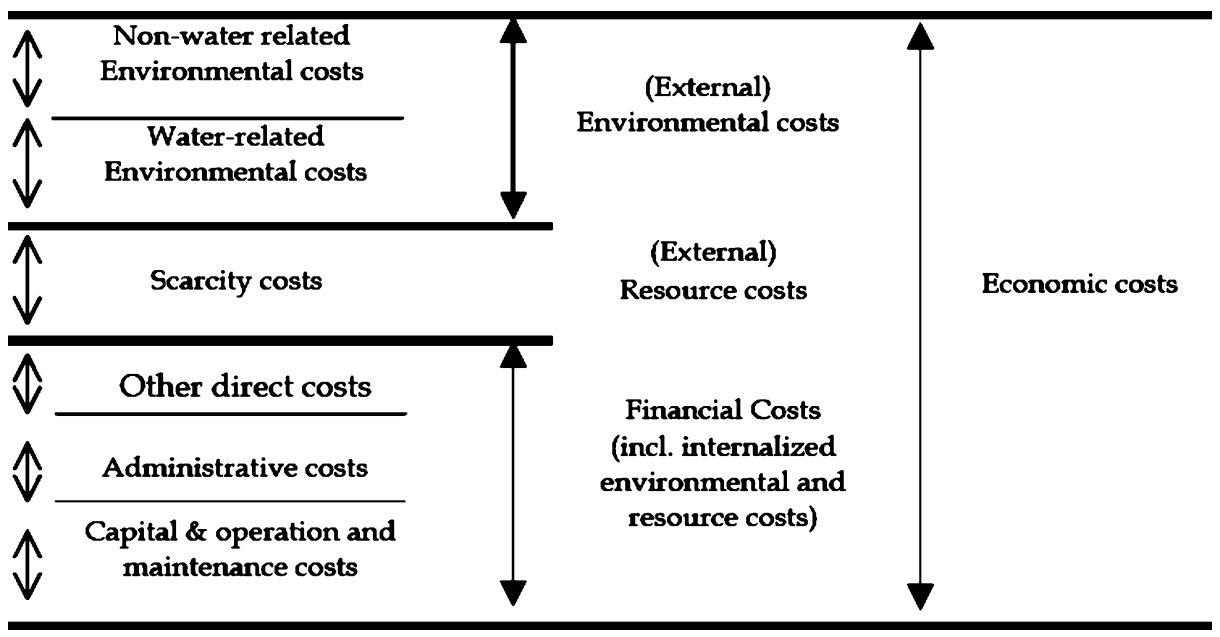

Fig. 1 Components of the full cost of water services (Source: WATECO 2002)

Member states shall take account "of the principle of recovery of the costs of water services, including environmental and resource costs, having regard to the economic analysis conducted according to Annex III, and in accordance with the polluter pays principle." Components of full water service cost are summarized in Fig. 1 (Rogers et al. 1998; WATECO 2002). Estimation of financial cost is the most straightforward. However, the definition and method of assessing resource and environmental costs for the purposes of the Directive remains controversial, and can cause difficulties in implementing this ambitious approach (WATECO 2002; Heinz 2005, 2006). A recently approved EC funded research project, AQUAMONEY (2006), is aimed to develop practical guidelines for the economic valuation of resource and environmental costs and benefits, which will be tested via a series of selected case studies of EU river basins. By 2010, States must ensure that water pricing provides incentives to use water efficiently and that users contribute "adequately" to water service costs.

\subsection{How can Hydro-economic Models Contribute to Achieving the WFD Targets?}

European water problems and basins have a diversity of problems and occur in a range of contexts of a vast geographic area. For such a great number of unique situations, computerbased hydrologic-economic water management models can help examine the feasibility of alternative water pricing policies and assess the cost-effectiveness and economic affordability of proposed programs and river management plans to achieve the WFD objectives. Four main applications of hydro-economic models for the European WFD will be discussed:

1. Economic, social (e.g., employment) and environmental impacts of water pricing.

2. Cost-effectiveness analysis of integrated management strategies for pollution control.

3. River basin modeling to analyze resource and environmental costs.

4. Participatory planning. 


\subsubsection{Socio-economic and Environmental Impacts of Water Pricing Policies}

The WFD recommends pricing policies to promote efficient water use and reduce pollution. Water pricing also should ensure cost recovery and create incentives for resource use efficiency. While employing water pricing for cost recovery may pose some problems for industrial, hydroelectric and urban users, pricing and cost recovery can be highly controversial for agricultural users (Dinar and Mody 2004; Blanco et al. 2004). This is especially true in many Mediterranean countries, where irrigated agriculture has an important socio-economic role and depends on a low water price. Agriculture is the main water user in these countries (80\% of water consumption in Spain). Agricultural intensification in these countries has significantly increased water and fertilizer use, with resulting environmental problems.

Many modeling studies in this region analyze the effects of water prices on irrigated agriculture. These model results show the impact of different cost-recovery alternatives on water consumption, cropping patterns, technology adoption, labor, farmers' incomes, environmental indicators (usually nitrogen pollution), and agency revenues. These are commonly mathematical programming models to simulate farmers' decisions applied at the irrigation district scale. The objective can be maximization of net farm income (sales value minus irrigation and other variable costs) or include several farming objectives, such as minimizing risk (e.g., the variance of income), total labor, or working capital (GomezLimon and Riesgo 2004). Water pollution by nitrates is a common environmental problem associated with agricultural activities. In these models nitrogen quantities in applied fertilizer is often employed as a proxy for water pollution (Blanco et al. 2004; Bazzani et al. 2004).

\subsubsection{Cost-effectiveness Analysis of Pollution Control}

Nitrogen pollution management models commonly allocate fertilizer use reductions among users through irrigation water prices, nitrogen fertilizer taxes, standards limiting nitrogen use, and taxes on pollution emissions. These models must couple hydrologic modeling (often at the basin or sub-basin scale) with simulation of water use and associated pollution. Gömann et al. (2005) couple agro-economic and environmental modeling with hydrologic modeling of surface and groundwater runoff. Modeling simulates reactive nitrate transport and degradation in groundwater, as well as groundwater borne nitrate inputs to rivers. The model allows comparative quantification of impacts of alternative nitrogen reduction actions (e.g., limiting livestock density and taxing nitrogen applications) and their costs in forgone agricultural income. The model is applied to the river Erms and a sub-catchment of the Rhine (Germany). Coordinated nitrate reduction and low flow improvement policies produce net benefits. Van der Veeren and Tol (2001) use game theory to analyze the allocation of nitrate emissions reduction that minimizes abatement and environmental costs for the Rhine river basin. By comparing different measures to maximize the difference between profits from polluting activities (crop production) and pollution cost, Martinez and Albiac (2004) find that higher water prices are inefficient for abating emissions in the Ebro basin (Spain). Ambient quality standards and emissions limits more effectively curb pollution.

The good ecological status required by the WFD implies achieving ambient pollution (water quality) standards and maintaining adequate river flows (water quantity) to prevent ecological damages. Aftab and Hanley (2004) present a model for a Scottish basin that 
estimates the cost of improving water quality for different minimum river flows. Other hydro-economic models deal with least cost water treatment strategies for municipal and industrial discharges (Jensen et al. 2002; Krejcik 2004).

\subsubsection{River Basin Modeling for Resource and Environmental Cost Assessment}

The assessment of resource and environmental cost (ERC) as one of the main issues regarding the WFD that requires further methodological development (WATECO 2002). Figure 1 shows these cost components in relation to the cost recovery principle as regulated in Article 9 of the WFD.

Resource cost was originally defined as "the cost of forgone opportunities that other users suffer due to the depletion of the resource beyond its natural rate of recharge or recovery" (WATECO 2002, Glossary, Annex II). This definition restricts resource cost to the overexploitation of depletable water stocks, i.e., mainly to aquifer overexploitation. Later, a European working group (ECO2) was set up to further clarify the concepts of ERC. This group embraced a different interpretation of resource cost as a result of the misallocation of water resources, rather than their overexploitation (Brouwer 2004). In this sense, resource cost can be related to the opportunity cost or forgone benefits in the best alternative use when a scarce resource is allocated (Young 2005). Opportunity costs always exist if water is scarce, either in quantity or quality, at a specific time and place (Brouwer 2004). Society should be attentive to the opportunity costs or resources will be misallocated. "Efficient water use is fundamentally about recognition of water's opportunity costs" (Griffin 2005). Theoretically, if water tariffs include this cost, an optimal resource allocation should be reached, marginal economic benefits of water would be equal across different uses, and society's water related welfare would be maximized. Despite the concept's apparent simplicity, measuring the opportunity cost of water is difficult. One option to simultaneously value and optimally allocate water may be to establish markets or tradable permits for water use or pollution. This approach is applied in some regions (Australia, California, Chile, and Spain), but is not yet generally accepted. Traditional and restrictive institutional conditions are often decisive (Spulber and Sabbaghi 1998). In the absence of well-functioning water markets, opportunity cost assessment requires "a systems approach and a number of more or less heroic assumptions about real impacts and responses to these" (Briscoe 1996). This assessment has to be based on a proper system to estimate the value of water for users in the system.

According to the conclusions of the ECO2 Group, environmental cost can be assessed as environmental damage cost or as damage avoidance (protection) cost (Brouwer 2004). WATECO (2002) Guidance defined environmental cost as the damage costs that water uses impose on the environment and ecosystems (including non-use values), and those who use the environment (use values). This is a benefit-based approach, as it typically assesses the cost of a damage through the forgone benefits if the damage occurs (Görlach and Interwies 2004). The foregone benefit of environmental damages can be estimated using direct (e.g., contingent valuation) or indirect (e.g., travel cost or hedonic pricing) environmental valuation methods. The study of the Elbe River shows that restoration of riparian wetlands provides significant benefits. Pretty et al. (2003) estimate that total damage of freshwater eutrophication in England and Wales is \$105-160 million/year. Economic valuation studies are often controversial and find practical difficulties in their application (Braden 2000).

The difficulty in assessing environmental costs as economic damages has led to an often more pragmatic alternative based on the use of avoided costs or the cost of measures to attain the good ecological status required by the Water WFD. Here, the cost of measures to 
prevent, avoid, or mitigate environmental damages are used as a proxy for the external environmental cost, which should be internalized somehow to reach the desired environmental goal (Brouwer 2004). The cost of measures already employed represents the environmental damage cost already internalized. However, the WATECO guidance specifies these as financial costs of water services (WATECO 2002). France has chosen to base its environmental cost calculation more on avoidance and restoration costs (Deronzier et al. 2005). A possible definition of environmental cost is the cost of future actions to achieve the good status required (Maestu et al. 2004). This cost will depend on the measures implemented to achieve environmental standards. The best combination of measures has to be defined through a cost-effectiveness analysis. Moreover, the economic benefits resulting from these measures should be estimated through the environmental damages reduced or prevented and the readiness of the society to pay for reducing environmental pressures. Integrated hydro-economic modeling can contribute to assess the environmental costs according to different definitions and help identify the costs (including resource and environmental costs) that should be incorporated in water prices corresponding to the cost recovery principle, as well as management approaches to reduce these costs.

\subsubsection{Role of Modeling in Participatory Processes}

Computer models, and hydro-economic models in particular, can have several roles within an institutional setting. Often, models merely serve a scientific purpose to improve understanding of system details, without a direct management role. However, models to support management or decision-making should address management roles as finely as scientific models are tailored to testing particular hypotheses. The roles of hydro-economic models for institutional and legal-political decision-making are typically more important than the form of model. Technical modeling decisions should be taken with the institutional client environment in mind, particularly in participatory settings. (Ideally, the institutional decision processes would adapt to the technical modeling environment as well. Alas, this is politically unrealistic.)

Models and data commonly evolve over long time periods, being adapted to help answer water management problems that often change more quickly in time. A typical example is the planning and operation of reservoirs with life-times of many decades. Within these lifetimes their purposes may change (for instance, recreation rather than water supply). This can lead to a lag between the development of models, data, and technical expertise and the problems considered important by management institutions and stakeholders resulting in economic losses due to mis-investment. Therefore, the development of data, models, and modeling expertise should be flexible and vary with the problem-setting. Ad hoc simulation or optimization models might be most suitable for episodic, one-time problems.

Integrated decision support systems (DSS), based on coupled sub-models of different domains, may help provide a framework for integrating data and models of different aspects of water systems into advice for stakeholders involved in system operations, planning, and policy-making (Andreu et al. 1996). Unfortunately, these aspects are rarely considered in original model design. However, recent research activities are dealing increasingly with this issue by elaborating the participatory role of water management models (Pahl-Wostl 2002; HarmoniCOP 2005; HarmoniQuA 2006).

Stakeholders contribute to model development, know the formal and informal rules governing decision-making (Pahl-Wostl 2002), and commonly participate in negotiations to 
develop agreements and contracts that better achieve all parties' objectives (win-win situations) (Heinz 2004). Some possible contributions of computer models in conflict resolution include: better scientific understanding of the problem, formalization of performance objectives and measures, developing promising alternative solutions, evaluation of the impact of various alternatives or policy changes (including hydrologic and ecological responses and economic consequences), providing technical confidence in the solutions, and providing a forum for negotiations (Loucks 1990; Lund and Palmer 1997).

There is some evidence that computer models can be helpful in negotiations. Shared Vision Planning combines a planning process with a structured public participation process, and computer-aided consensus building techniques. Shared vision models are computer simulation models developed jointly by stakeholders and water managers (Palmer et al. 1999). Some DSS have incorporated friendly graphical-user interfaces, allowing people who are not modelers to define the system, enter appropriate data, and test their own management alternatives and display the results in various meaningful ways.

\section{An Example of Application of Hydro-economic Modeling Related to the WFD}

A method for systematic assessment of resource cost at different locations is applied to the Jucar Pilot River Basin in Eastern Spain (Andreu et al. 2005; Pulido-Velazquez et al. 2006). The method is based on integrated hydro-economic simulation and optimization models at the river basin scale, and applies the the concept of marginal resource opportunity cost (MROC). MROC is defined as the cost to the system of having one unit less of resource at a specific location and time. This value indicates the aggregated "economic impact" of water scarcity (forgone economic net benefits) and helps quantify how much the users would be willing to pay to reduce that scarcity (considering only use-values, although other identified non-use values could be added). Spatial and temporal variability in resource value can only be captured by hydro-economic modeling that integrates demand, resources, and infrastructure under realistic operating rules. Hydro-economic simulation and optimization models provide complementary measures of these opportunity costs. If the objective function of the model is the aggregated economic net benefit from water use, the optimization approach will yield time series of the evolution of the marginal economic value of water at certain locations (or MROC) from the shadow prices (or Lagrange multipliers) associated to the water availability constraints (eg., Jenkins et al. 2001; Pulido-Velazquez et al. 2004; Pulido-Velazquez et al. 2006). The MROC therefore corresponds to the change in the basinwide aggregated economic net benefit due to an additional unit of water at that time and location. These results correspond to the economically optimal water allocation, which could be theoretically obtained in an ideal situation of perfect water markets. Optimization model results also provide insights on possible operational or infrastructural strategies or policy actions (e.g., optimal water pricing) to improve economic results.

The simulation approach assumes the system is managed by fixed operating rules and institutional constraints, typically corresponding to historical priorities and rights. Therefore, economics does not drive water allocation, and the economic analysis reflects the results of system operation under the current institutional setting (or other policies being tested). An equivalent procedure to estimate the MROC under this simulation approach has been developed and applied to different practical cases (Andreu et al. 2005). MROC through time at a specific location is assessed through successive simulations as the cost to 
water users in the system (expressed as forgone net benefits) of having one unit less of resource at that specific location and time. Comparison of optimization and simulation results provides insights on the physical and institutional origins of resource costs, as well as other economic assessments.

Hydro-economic models can be developed ad hoc for a specific system or using generic integrated Decision Support System (DSS) tools. New modules of the DSS system AQUATOOL incorporate tools that support the proposed simulation and optimization method for quantifying MROC. These tools are tested for the Jucar River Basin with results consistent with expected economic behavior (CHJ 2005). Figure 2 shows the MROC at Tous reservoir from the simulation approach, showing that MROC is higher during droughts and drier years. The maximum MROC corresponds to the drought of 1994-1995, and is driven by shortages to agricultural and urban users. MROC should vary in time and space with water scarcity.

Another hydro-economic model, the Water StrategyMan DSS applies a simulation approach to estimating resource cost (and environmental cost) for the island of Paros (Greece) and other European basins (Assimacopoulos et al. 2005). Both Water StrategyMan and AQUATOOL deal with resource costs in relation with the economic value of water, but from different points of view. Whereas the Water StrategyMan DSS is based on the simultaneous consideration of scarcity rent and environmental cost, the DSS Aquatool applies the concept of penalty functions expressing the economic benefits forgone due to water scarcity in the different water uses to estimate the MROC. Both approaches indicate that the true economic value of water exceeds financial water supply costs if water scarcity prevails (Heinz 2006). Thus hydro-economic models can assist water pricing policies.

\section{MROC in Tous reservoir}

\section{$€ / \mathrm{m}^{3}$}
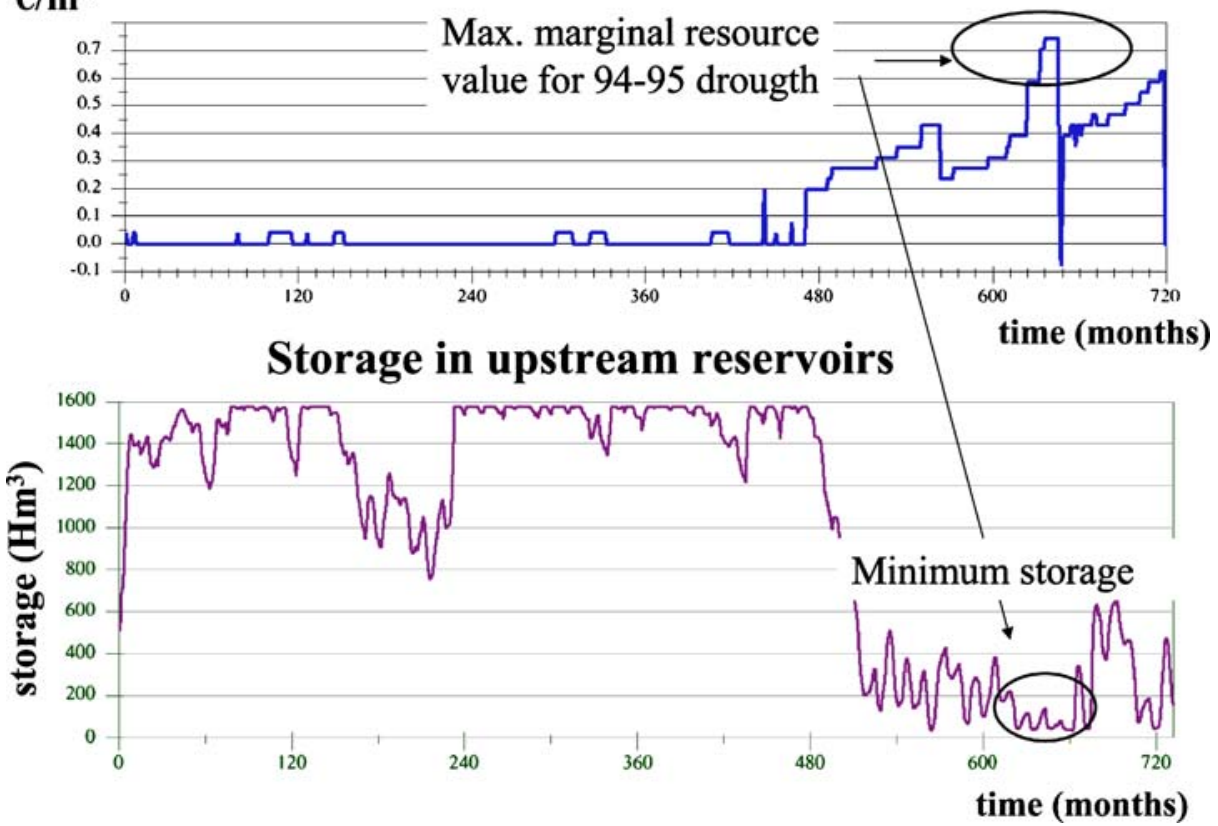

Fig. 2 MROC and storage at the Tour reservoir, in the Júcar River Basin (Spain)

\section{Springer}


Minimum ecological streamflow or minimum reservoirs' storage requirements are among the actions to achieve good ecological status for water bodies. These environmental requirements impose changes in operation and water allocation and can lead to opportunity costs for other users. As with the MROC, the marginal opportunity cost of environmental requirements (MOCER) can be assessed as the cost to the system of increasing an environmental constraint by one unit (Pulido-Velazquez 2003), which in the optimization model can be estimated from the shadow value of environmental constraints (e.g., Jenkins et al. 2001; Pulido-Velazquez et al. 2006). Environmental operating constraints also are measures to improve ecological quality (through flow augmentation) and thus are part of the measures whose potential cost has to be evaluated to identify the most cost-efficient combination of alternatives.

\section{Conclusions}

River basin management has become more complex than traditional hydraulic engineering or hydrology. River systems are being used more intensely by a larger and more diverse set of water users and uses, including water quality issues. Water users and managers are employing and considering a wider and more integrated range of management options and alternatives. Water resource management decisions and governance are also more decentralized and participatory than in the past, involving a variety of local, regional, national, and international governments, interests, and stakeholders. This larger set of users, uses, and managers is increasingly concerned with demonstrating quantitative performance of water resource systems over a wider range of conditions and scenarios.

Economics provides ideas and methods to better inform decision making on waterrelated problems. Economic techniques can help us assess consequences of alternative water policies and management and information for decision makers and participatory process regarding optimal allocations or more efficient use of scarce water resources among competing parties.

Effective water management combines economic concepts and methods with engineering and hydrologic expertise. Computer modeling provides an effective and efficient means to integrate modern economics, water resource engineering, and hydrology. Integrated hydro-economic models can suggest least-cost combinations of actions to attain specified goals and examine how alternative choices will affect different interests. DSS computer models can be helpful in participatory and negotiation processes, supporting more rational and well-informed decisions and consensus-building among the different stakeholders based on a common understanding and model of the problem and socio-economic implications of solutions (Andreu et al. 2006).

Economic-engineering-hydrologic models and management concepts have been applied to many water systems worldwide, and the recent European Union Water Framework Directive provides significant opportunities for further development of this crossdisciplinary field. The Directive clearly integrates economics into water management and policy making, calling for the application of economic principles (e.g., the polluter pays principle), approaches (e.g., cost-effectiveness analysis), and instruments (e.g., water pricing). Economic theory and hydro-economic modeling tools provide promising tools for implementing the WFD. Key tasks for the near future are to improve and integrate these technical approaches into participatory and decision-making processes so we can better cope with the increasing challenges in water resources management. 


\section{References}

Aftab A, Hanley N (2004) Combining economic instruments with regulation to achieve dual environmental targets: nitrate pollution and minimum river flows, In: Applied environmental economic conference. ENVECON 2004. The Royal Society, London. http://www.eftec.co.uk/home.php?section=8\&uknee=2)

Andreu J, Capilla J, Sanchís E (1996) AQUATOOL, a generalized decision support system for waterresources planning and management. J Hydrol 177:269-291

Andreu J, Pulido-Velazquez M, Collazos G (2005) Methodology and tools for integrated assessment of resource and environmental costs. In: Second international workshop on implementing economic analysis in the water framework directive. Paris, France, pp 17-18 (February)

Andreu J, Solera A, Paredes J, Sanchez S (2006) Decision support systems for integrated water resources planning and management. In: International workshop on "Hydro-economic modelling and tools for the implementation of the EU water framework directive." Valencia, Spain, pp 30-31 (Jan 2006)

AQUAMONEY (2006) http://www.aquamoney.org/

Assimacopoulos D, Barraque D, Berland J-M, Feinerman E, Katsiardi P, Manoli E (2005) Estimation of the level of cost recovery of different scenarios of water allocation in arid areas. An easy-to-implement approach. In: Second international workshop on implementing economic analysis in the water framework directive (Seine-Normandy Water Agency and the Directorate of Environment of the EU Commission). Paris, France, 17-18 (Feb)

Bazzani GM, Di Pasquale S, Gallerani V, Viaggi D (2004) Irrigated agriculture in Italy and water regulation under the European Union water framework directive. Water Resour Res 40, W07S04, doi 10.1029/ 2003WR002201

Bish R (1982) Governing Puget Sound. Sea Grant. Seattle, Washington

Blanco M, Iglesias E, Sumpsi JM (2004) Environmental and socioeconomic effects of water pricing policies: key issues in the implementation of the water framework Directive. In: 13th annual EAERE conference. Budapest, Hungary

Booker JF, Young RA (1994) Modeling intrastate and interstate markets for Colorado River water resources. J Environ Econ Manage 26:66-87

Braden JB (2000) Value of valuation: introduction. J Water Resour Plan Manage 126(6):336-338

Briscoe J (1996) Water as an economic good. The idea and what it means in practice. In: Proceedings of the world congress of the International Commission on Irrigation and Drainage (ICID). Cairo, Egypt

Brouwer R (2004) The concept of environmental and resource cost. Lessons learned from ECO2. In: Brouwerand R, Strosser P (eds) Environmental and resource cost and the water framework directive. An overview of European practices. RIZA Working Paper 2004. 112x, Amsterdam, Holland

Burke SM, Adams RM, Wallender WW (2004) Water banks and environmental water demands: case of the Klamath project. Water Resour Res 40:W09S02, doi:10.1029/2003WR002832

Cai X, McKinney DC, Lasdon LS (2003) Integrated hydrologic-agronomic-economic model for river basin management. J Water Resour Plan Manage 129(1):4-17

Cai X, Rosegrant MW (2004) Optional water development strategies for the Yellow River Basin: balancing agricultural and ecological water demands. Water Resour Res 40(4), doi:10.1029/2003WR002488

CHJ (Júcar Water Agency) (2005) Provisional Art. 5 Report Pursuant to the Water Framework Directive. Confederación Hidrográfica del Júcar, Ministry of Environment, Spain

Deronzier P, Feuilette S, Chegrani P (2005) Environmental costs: from theory to practice in France. In: Second international workshop on implementing economic analysis in the water framework directive. Paris, France, pp 17-18 (February)

Dinar A, Mody J (2004) Irrigation water management policies: allocation and pricing principles and implementation experience. Nat Resour Forum 28(2):112-122

Dirksen F (2004) Beyond linking model systems. In: Heinz I, Nagandla K, Dirksen F (eds) Expert meeting on economics in water management models, Copenhagen, Denmark, pp 15-16 (November) http://hit. infu.uni-dortmund.de/login.html, userid: Copenhagen, password: EconoMod

Dirksen PW, Blind MW, Bomhof T, Nagandla K (2005) Proof of concept of OpenMI for visual DSS development. In: MODSIM05 Conference, Australia

Disco C (2002) Remaking nature: the ecological turn in dutch water management. Sci Technol Human Values 27(2):206-235 (Spring)

Draper AJ, Jenkins MW, Kirby KW, Lund JR, Howitt, RE (2003) Economic-engineering optimization for California water management. J Water Resour Plan Manage 129(3):155-164

Dupuit J (1844) De la mesure de l'utilité des travaux publics. Annales des Ponts et Chaussées, Memoirs et Documents, 2nd ser. 8(2):332-375 
Elelund RB, Hebert RF (1999) The secret origins of modern microeconomics: dupuit and the engineers. University of Chicago Press. Chicago, Illinois

EU Commission (2000) Directive 2000/60/EC of the European Parliament and of the Council, of 23 October 2000, establishing a framework for Community action in the field of water policy. Official Journal of the European Economics L 327/1,22.12.2000: http://europa.eu.int/comm/environment/water/water-framework/ index_en.html

Frontinus SJ (97A.D.) The water supply of the City of Rome (translation by C. Herschel)

Garcia S, Reynaud A (2004) Estimating the benefits of efficient water pricing in France. Resour Energy Econ 26(1):1-25

Gömann H, Kreins P, Kunkel R, Wendland F (2005) Model based impact analysis of policy options aiming at reducing diffuse pollution by agriculture - a case study for the river Ems and a sub-catchment of the Rhine. Environ Model Softw 20(2):261-271

Görlach B, Interwies E (2004) Assessing environmental and resource costs in the water framework directive: the case of Germany. In: Ecologic - Institute for International and European Environmental Policy. Berlin, Germany. http://www.ecologic.de/download/projekte/1950-1999/1970-01/erc_germany.pdf/

Gomez-Limon JA, Riesgo L (2004) Water pricing: analysis of differential impacts on heterogeneous farmers. Water Resour Res 40, W07S05, doi:10.1029/2003WR002205

Gorelick SM (1983) A review of distributed parameter groundwater management modeling methods. Water Resour Res 19(2):305-319

Griffin RC (2005) Water resource economics. The analysis of scarcity policies and projects. MIT, Cambridge, Massachusetts, USA, p 402

HarmoniCOP (2005) Harmonising collaborative planning. Improving participation in water management, http://www.harmonicop.info/HarmoniCOPHandbook.pdf

HarmoniQuA (2006) Harmonising quality assurance in model based catchment and river basin management. In: Final report of the research project funded by the European Commission, http://www.HarmoniQuA.org/

HEC (1996) Application of HEC-PRM for seasonal reservoir operation of the Columbia River System, Report RD-43, Army Corps of Engineers, Hydrologic Engineering Center, Davis, California

Heinz I (2004) Sustainable farming as a result of negotiations: an analysis at European level, 7th InterRegional Conference on Environment-Water. In: 2004 CIGR international conference. International Commission of Agricultural Engineering. Beijing, China, pp 11-14(October) http://www.infu. uni-dortmund.de/english/Co-workers/Ingo.Heinz

Heinz I (2005) How can the WFD cost categories made more feasible? Second International Workshop on Implementing Economic analysis in the Water Framework Directive, Paris pp 17-18 (February) http:// www.infu.uni-dortmund.de/english/Co-workers/Ingo.Heinz

Heinz I (2006) The economic value of water, paper and presentation prepared for the international workshop on "Hydro-economic Modeling and Tools for the Implementation of the European water framework directive." Valencia, pp 30-31 (January) http://www.infu.uni-dortmund.de/english/Co-workers/Ingo. Heinz

Interwies E, Kraemer RA et al (2004) Basic principles for selecting the most cost-effective combination of measures for inclusion in the program of measures as described in article 11 of the water framework directive. UBA - Texte 24/04. Ecologic. Berlin, Germany

Jacobs J, Freeman G, Grygier J, Morton D, Schultz G, Staschus K, Stedinger J (1995) SOCRATES: a system for scheduling hydroelectric generation under uncertainty. Ann Oper Res 59:99-133

Jenkins MW, Lund JR (2000) Integrated yield and shortage management for water supply planning. J Water Resour Plan Manage 126(5):288-297

Jenkins MW, Draper JD, Lund JR, Howitt RE et al (2001) Improving California water management: optimizing value and flexibility, Center for Environmental and Water Resources Engineering, Report no.01-1, University of California, Davis, California, USA

Jenkins MW, Lund JR, Howitt RE, Draper AJ, Msangi SM, Tanaka SK, Ritzema RS, Marques GF (2004) Optimization of California's water system: results \& insights. J Water Resour Plan Manage 130(4):271-280

Jensen RA, Krejcik J, Malmgren-Hansen A, Vanecek S, Havnoe K, Knudsen J (2002) River basin modelling in the Czech Republic to optimise interventions necessary to meet the EU environmental standards. In: Proceedings of the international conference of basin organisations, Madrid, Spain, pp 4-6 (November)

Jöborn A, Danielsson I, Arheimer B, Jonsson A, Larsson MH, Lundqvist LJ, Löwgren M, Tonderski K (2005) Integrated water management for eutrophication control: public participation, pricing policy, and catchment modeling. Ambio XXXIV(7):482-488

Krejcik A (2004) River basin modelling in the Czech Republic-2. In: Expert meeting on economics in water management models, Copenhagen, Denmark, pp 15-16 (November), http://hit.infu.uni-dortmund.de/ login.html, userid: Copenhagen, password: EconoMod 
Lee DJ, Howitt RE (1996) Modeling regional agricultural production and salinity control alternatives for water quality policy analysis. Am J Agric Econ 78:41-53

Lefkoff J, Gorelick SM (1990) Simulating physical processes and economic behavior in saline, irrigated agriculture: model development. Water Resour Res 26(7):1359-1369

Loucks P (1990) Analytical aid to conflict management. In: Viesssman W, Smerdon ET (eds) Managing water-related conflicts: the engineers role. ASCE, New York, pp 23-37

Lund JR, Ferreira M (1996) Operating rule optimization for the Missouri River Reservoir System. J Water Resour Plan Manage 122(4):287-295

Lund JR, Palmer RN (1997) Water resources system modelling for conflict resolution, Water Resources Update, n. 108. Universities Council on Water Resources (UCOWR). Carbondale, Illinois, US

Maestu J, Andreu J, Gomez CM (2004) Practical experiences in Spain. In: Brouwer R, Stosser P (eds) Environmental and resource cost and the water framework directive (An overview of European practices). RIZA Working Paper 2004. Amsterdam, Holland, p 112x

McCarl BA, Dillon CR, Keplinger KO, Williams RL (1999) Limiting pumping from the Edwards Aquifer: an economic investigation of proposals, water markets, and spring flow guarantees. Water Resour Res 35 (4):1257-1268

Martinez Y, Albiac J (2004) Agricultural pollution control under Spanish and European environmental policies. Water Resour Res 40, W10501, doi:10.2005/2004WR003102

Mejías P, Varela-Ortega C, Flichman G (2004) Integrating agricultural policies and water policies under water supply and climate uncertainty. Water Resour Res 40, W07S03, doi 10.1029/2003WR002877

MMA (2002) Análisis Económico del Plan de Cuenca del Cidacos. Ministerio de Medio Ambiente-Gobierno de Navarra

Morris J (2004) Economics and the water framework directive: purpose, principles and practice. In: Applied Environmental Economic Conference, ENVECON 2004 (http:/www.eftec.co.ukhome.php?section=8\&uknee=2). The Royal Society, London

Pahl-Wostl C (2002) Participative and stakeholder-based policy design, evaluation and modelling processes. Integrated Assessment 3(1):3-14

Palmer Richard N, Werick William J, MacEwan Allison, Woods Andrew W (1999) Modeling water resources opportunities, challenges and trade-offs: the use of shared vision modeling for negotiation and conflict resolution. In: ASCE conference proceedings

Pretty JN, Mason CF, Nedwell DB, Hine RE, Leaf S, Dils R (2003) Environmental cost of freshwater eutrophication in England and Wales. Environ Sci Technol 37(2):201-208

Pulido-Velazquez M (2003) Economic optimization of the management of conjunctive use of surface and groundwater in a water resources system. Contribution to the economic analysis proposed by the European water framework directive. PhD dissertation (in Spanish), Technical University of Valencia, Spain

Pulido-Velazquez M, Jenkins MW, Lund JR (2004) Economic values for conjunctive use and water banking in Southern California. Water Resour Res 40(3) March

Pulido-Velazquez M, Andreu J, Sahuquillo A (2006) Economic optimization of conjunctive of surface and groundwater at the basin scale. J Water Resour Plan Manage 132(6)

Raiffa H (1984) The art and science of negotiation. Harvard University Press, Cambridge, Massachusetts

Rogers P, Bhatia R, Huber A (1998) Water as a social and economic good: how to put the principles into practice. In: Global Water Partnership, TAC Background Paper n.2. Stockholm, Sweden

Rogers P, de Silva R, Bhatia R (2002) Water is an economic good. How to use prices to promote equity, efficiency and sustainability. Water Policy 4(2002):1-17

Shortle JS, Dunn JW (1986) The relative efficiency of agricultural source water pollution control policies. Am J Agric Econ 68:668-677

Spulber N, Sabbaghi A (1998) Economics of water resources: from regulation to privatization. Kluwer, Boston, Massachusetts

Strosser P (2004) The economic elements of the EU water framework directive, expert meeting on economics in water management models, Copenhagen, Denmark, pp 15-16 (November), http://hit.infu.uni-dortmund. de/login.html, userid: Copenhagen, password: EconoMod

U.S. Water Resources Council (1983) Economic and environmental principles and guidelines for water and related land resources implementation studies. U.S. Government Printing Office, Washington, District of Columbia. Available at http://www.wrsc.usace.army.mil/iwr/pdf/p\&g.pdf

Van der Veeren RJHM, Tol RSJ (2001) Benefits of a reallocation of nitrate emission reductions in the Rhine River Basin. Environ Resour Econ 18:19-41

Van der Veeren R (2005) In pursuit of optimal measure packages. Dutch Handbook on cost-effectiveness analysis for the EU water framework directive. Ministerie van Verkeer en Waterstraat. The Netherlands 
WATECO (2002) Economics and the environment. The implementation challenge of the water framework directive. A guidance document. Working group for WFD economic studies

Watkins DW, McKinney DC (1999) Screening water supply options for the Edward aquifer region in Central Texas. J Water Resour Plan Manage 125(1):14-24

Westen S, Fortune D, Gregersen J (2004) OpenMI - New opportunities for model developers. In: Liong, Phoon and Babovic (eds) 6th international conference on Hydroinformatics - World Scientific Publishing Company, ISBN 981-238-787-0

Winpenny JT (2003) Financing water for all. Report on the World Panel on Financing Water Infrastructure, World Water Council. 3rd World Water Forum and Global Water Partnership

Young RA (2005) Determining the economic value of water. Resources for the Future, Baltimore, Maryland Young HP, Okada N, Hashimoto N (1982) Cost allocation in water resources development. Water Resour Res 18:463-475 